DOI: $10.14451 / 2.156 .51$

\title{
ПРОБЛЕМЫ ПРИМЕНЕНИЯ ИНСТИТУТА НЕОСНОВАТЕЛЬНОГО ОБОГАЩЕНИЯ ПРИ ВЗЫСКАНИИ НАЛОГОВ
}

\author{
(c) 2021 Кукушкин Дмитрий Сергеевич
}

Московский государственный юридический университет имени О.Е. Кутафина, Россия, Москва

В российской правоприменительной практике по налоговым спорам сложилось стойкое убеждение в том, что у налоговых органов имеются чересчур широкие полномочия по использованию гражданско-правовых механизмов в целях взыскания налоговой задолженности у налогоплательщиков. Однако зачастую такое положение дел расшатывает публично-правовой правопорядок, поскольку институты частного права создавались в иных целях и на основании принципов, отличных от тех, которые закреплены в общих положениях налогового законодательства. Показательным примером такого некорректного использования гражданско-правовых норм в публичных правоотношениях стало использование института неосновательного обогащения в целях взыскания налоговой задолженности. Именно о неправомерности использования данного механизма речь пойдет в настоящей статье в контексте анализа Постановления Конституционного Суда РФ N 9-П от 24 марта 2017 года.

Ключевые слова: неосновательное обогащение, кондиционный иск, налоговое законодательство, взыскание налоговых платежей.

В свете принятия Конституционным судом РФ Постановления N 9-П от 24 марта 2017 года" одной из дискуссионных проблем в сфере налогообложения стало положение о возможности взыскания налога путем применения института неосновательного обогащения к публичным правоотношениям по взысканию налогов.

Прежде чем перейти к обсуждению данной проблемы, необходимо определиться с самой природой института неосновательного обогащения и его назначения в действующем гражданском правопорядке.

Легальное определение обязательства вследствие неосновательного обогащения содержится в ст. 1102 ГК РФ и состоит из следующих условий для его применения:

a) происходит приобретение имущества либо избавление от трат;

б) происходит уменьшение в имущественной сфере у потерпевшего;

в) отсутствуют основания, предусмотренные законом, иными правовыми актами или сделкой, для такого обогащения."
Необходимо также помнить, что институт неосновательного обогащения является общей защитной мерой, которая субсидиарно применяется к иным установленным в ст. 1103 ГК РФ требованиям о возврате имущества. Условия для предъявления общего кондиционного иска, основанного на ст. 1102 ГК РФ, возникают лишь в тех случаях, когда возникшее положение неоправданного увеличения имущества одного лица за счет другого не может быть устранено с помощью иных охранительных мер, носящих специальный характер.

В цивилистике обоснованно отмечается, что кондикция подлежит применению лишь тогда, когда специальный иск потерпевшему недоступен в силу объективных причин (отсутствие оснований для применения специального иска как такового), а не ввиду ограничений, установленных законодателем из соображений правовой политики, препятствующих удовлетворению иска при наличии условий субъективного характера (например, пропуск срока исковой давности). Кондикицонный иск не может использо-

\footnotetext{
* Постановление Конституционного Суда РФ от 24.03.2017 N 9-П «По делу о проверке конституционности отдельных положений Налогового кодекса Российской Федерации и Гражданского кодекса Российской Федерации в связи с жалобами граждан Е.Н. Беспутина, А. В. Кульбацкого и В.А. Чапланова» // «Вестник Конституционного Суда РФ», N 4, 2017.

**; Гражданское право: учебник: в 2 т. / О. Г. Алексеева, Е.Р. Аминов, М. В.Бандо и др.; под ред. Б. М. Гонгало. 3-е изд., перераб. и доп. М.: Статут, 2018. Т. 2.- 560 с.
} 
ваться с целью обхода закона."

Таким образом, институт неосновательного обогащения, являясь общей защитной гражданско-правовой мерой, имеет субсидиарную по отношению к иным охранительным требованиям природу. При этом свойство «резервности» данного института не должно использоваться с целью обхода установленных законом ограничений.

При этом действующее налоговое законодательство содержит множество механизмов, позволяющих налоговому органу обеспечивать в административном порядке наполняемость бюджета и осуществлять контроль за уплатой налогов. K таковым относятся выездные и камеральные налоговые проверки (ст. 88 и $89 \mathrm{HK}$ РФ), повторные выездные налоговые проверки вышестоящими налоговыми органами в порядке контроля за деятельностью налогового органа, проводившего проверку (п. 10 ст. 89 НК РФ), принудительное взыскание налога за счет имущества налогоплательщика (ст. 46 НК РФ) и др.

Для того чтобы не допустить необоснованное вмешательство налоговых органов в деятельность налогоплательщика, указанные механизмы в НК РФ намеренно ограничены определенными в НК РФ процедурами и сроками. В частности, налоговые органы по общему правилу могут проверить только три года, предшествующие году вынесения решения о проведении выездной налоговой проверки (п. 4 ст. 89 НК РФ), они не могут запрашивать документы в отсутствие на то правовых оснований (п. 7 ст. 88 НК РФ) и др.

Таким образом, законодатель сознательно закрепил в законе специальные механизмы, которыми должны руководствоваться налоговые органы для защиты своих публичных интересов. Однако контролирующие органы не могут их применять в случае, к примеру, пропуска предусмотренных НК РФ сроков, позволяющих провести соответствующие мероприятия налогового контроля и взыскать необоснованно вы- плаченный физическому лицу вычет. В таком случае использование механизма неосновательного обогащения невозможно, поскольку этот метод будет применен в обход ограничений, которые предусмотрены НК РФ, что противоречит сложившемуся правопорядку.

Чрезмерный и необоснованный налоговый контроль на сегодняшний день является распространенной проблемой, которую часто можно встретить на практике. Между тем Конституционный суд РФ в Постановлении № 14-П от 16.07.2004 достаточно определенно сформулировал принцип, согласно которому «НК РФ исходит из недопустимости причинения неправомерного вреда при проведении налогового контроля»."

Между тем использование налоговыми органами механизмов неосновательного обогащения как раз-таки и представляет собой яркий пример чрезмерного и необоснованного вмешательства в экономическую сферу налогоплательщика в силу неправомерного использования кондиционного иска в адрес последнего.

Также необходимо заметить, что мы не можем подобным образом применять к налоговым правоотношениям механизмы, находящиеся за рамками императивных норм налогового права, поскольку пунктом 3 статьи 2 ГК РФ прямо закреплено следующее: «к имущественным отношениям, основанным на административном или ином властном подчинении одной стороны другой, в том числе к налоговым и другим финансовым и административным отношениям, гражданское законодательство не применяется, если иное не предусмотрено законодательством».

Как обоснованно отмечается в литературе, запрет такого рода продиктован существенными различиями в методах регулирования отношений, присущих, с одной стороны, отраслям частного права, каковым является гражданское право, и, с другой стороны, отраслям публичного права, в том числе административного, финан-

\footnotetext{
* НовакД.В.Неосновательное обогащение в гражданском праве / Российская школа частного права.- Москва: Статут, 2010.- 384 с. Шраге Э. Несправедливое обогащение / В кн.: Юридическая наука и преподавание права: проблемы и перспективы. Международный сборник научных трудов / Под ред.д.ю.н., проф. В. В.Бойцовой, д.ю.н., проф. Л. В. Бойцовой. - Тверь, 1996. - 92-93 с.

** Постановление Конституционного Суда РФ от 16.07.2004 N 14-П «По делу о проверке конституционности отдельных положений части второй статьи 89 Налогового кодекса Российской Федерации в связи с жалобами граждан А.Д.Егорова и Н. В. Чуева» // «Вестник Конституционного Суда РФ», N 6, 2004.
} 
сового, налогового права."

Федеральным налоговым законодательством исключений из этого правила применительно к использованию института неосновательного обогащения не установлено.

Между тем, по мнению М.В. Карасевой (Сенцовой), в Постановлении Конституционного суда N 9-П от 24 марта 2017 года суд сделал вывод о необходимости использования применительно к данной ситуации института неосновательного обогащения, потому что указанный механизм, якобы, «представляет собой конкретизированное нормативное выражение общеправовых принципов равенства и справедливости, лежащих в основе российского конституционного правопорядка», а также в связи с конституционным требованием о «недопустимости осуществления прав и свобод человека и гражданина в нарушение прав и свобод других лиц». Таким образом, по мнению ученого, вывод суда никак не связан и не ограничен п. 3 ст. 2 ГК РФ, в котором отмечено, что к налоговым отношениям гражданское законодательство не применяется.***

Все это изначально звучит довольно убедительно, однако трудно согласиться с доводом о том, что Конституционный суд РФ принял решение, не идущее в разрез с п. 3 ст. 2 ГК РФ. Даже если принять тот факт, что при решении возникшей проблемы суд руководствуется лишь нормативным закреплением общеправовых и конституционных принципов права, выходит, что при их реализации мы должны перемеситься в плоскость гражданского права и использовать институт, который является носителем этих принципов и содержит регламентированный нормами иной отрасли механизм решения данной проблемы. Мы в любом случае «вторгаемся» в отрасль гражданского права, как бы это не пытался обойти в своем акте Конституционный суд РФ. Если суд при решении спорной ситуации сочтет необходимым разрешить дело, применив общеправовые принципы права, то он это может сделать и с применением публично правовых институтов, при условии, что данные принципы не будут противоречить налоговому законодательству.

Более того, считаем обоснованным мнение о том, что применение кондикционных обязательств как раз-таки противоречит требованию о «недопустимости осуществления прав и свобод человека и гражданина в нарушение прав и свобод других лиц», поскольку в этом случае нарушаются права налогоплательщика на неприкосновенность собственности, которую изъяли в интересах казны в противоправном порядке.

На необоснованность применения институтов гражданского права в свое время указывал и Пленум Верховного Суда РФ в п. 38 Постановления от 24.03.2016 N 7 «О применении судами некоторых положений Гражданского кодекса Российской Федерации об ответственности за нарушение обязательств».*** Еще раньше указанная позиция отмечалась в п. 2 совместного одноименного Постановления Пленума Верховного Суда РФ N 6, Пленума ВАС РФ N 8 от 01.07.1996. ****

Необходимо отметить, что если бы законодатель посчитал необходимым применить определенные гражданско-правовые механизмы (например, институт неосновательного обогащения в целях взыскания задолженности) к отдельным аспектам налогового администрирования, то он бы регламентировал их в кодексе, добавив в них отдельные публично-правовые компоненты в целях обеспечения соблюдения баланса частных интересов налогоплательщиков как «слабой», менее защищенной стороны налоговых отношений и публичных интересов казны, на стороне которых находится более сильный субъект указанных правоотношений.

Примеров подобных внедрений в действующее налоговое законодательство на текущий момент уже не так уж и мало. Достаточно вспомнить способы обеспечения исполнения налоговой обязанности (глава 11 НК РФ). Так, законода-

\footnotetext{
* Гражданский кодекс Российской Федерации. Постатейный комментарий к главам 1, 2, 3 / Б. М.Гонгало, А. В.Коновалов, П. В. Крашенинников и др.; под ред. П. В. Крашенинникова. М.: Статут, 2013. - 27 с.

** Карасева (Сенцова) М.В.Гражданско-правовые меры принуждения в налоговой сфере и защита прав налогоплательщиков // Финансовое право. 2017. N 10.- 29 с.

**** Постановление Пленума Верховного Суда РФ от 24.03.2016 N 7 «О применении судами некоторых положений Гражданского кодекса Российской Федерации об ответственности за нарушение обязательств» // «Российская газета», N 70, 04.04.2016.

**** Постановление Пленума Верховного Суда РФ N 6, Пленума ВАС РФ N 8 от 01.07.1996 «О некоторых вопросах, связанных с применением части первой Гражданского кодекса Российской Федерации»// «Российская газета», N 152, 13.08.1996
} 
тель предусмотрел возможность использования налогоплательщиком института налогового поручительства в качестве меры, обеспечивающей возможность последнего исполнить налоговую обязанность силами третьего лица в случае, если у самого налогоплательщика для этого отсутствуют соответствующие ресурсы, а налоговому органу, в свою очередь, в этом случае предоставляется гарантия уплаты обязательных платежей в предусмотренные законом сроки и не нанесение ущерба казне.

Кондикционное обязательство не направлено на защиту «слабой» стороны правоотношений с учетом соблюдения интересов «сильной» стороны, поскольку правовой статус сторон гражданских правоотношений является равным по общему правилу.

В связи с этим институт неосновательного обогащения в его «чистом» частноправовом смысле не приспособлен для нужд справедливого налогового администрирования. Именно поэтому в целях недопущения нарушения прав субъектов публичных правоотношений (в том числе и субъектов налоговых правоотношений) законодатель в п. 3 ст. 2 ГК РФ предусмотрел превентивную меру по запрету произвольного применения гражданско-правовых конструкций к правоотношениям, где стороны не равны в своем правовом статусе.
Таким образом, обоснованным считается мнение о том, что применение института неосновательного обогащения в качестве механизма по взысканию налогов является недопустимым в сложившемся российском правопорядке по нескольким причинам.

Во-первых, поскольку законодатель создал специальные предусмотренные НК РФ механизмы для защиты публичных интересов по взысканию налогов, а также установил соответствующие процессуальные сроки для их реализации, применение института неосновательного обогащения за пределами установленных законодателем ограничений недопустимо, поскольку ведет к использованию кондикционного требования в обход закона.

Во-вторых, сам ГК РФ закрепляет общее правило, согласно которому применение гражданское законодательства не применяется к имущественным налоговым отношениям. При этом для нашего случая закон исключений не предусматривает. Ссылки судов на применение кондикционного требования в качестве конституционного принципа справедливости также, на мой взгляд, являются несостоятельными, поскольку они так или иначе ведут к применению гражданского законодательства, что в соответствии с законом является недопустимым.

\section{Литература}

1. Гражданское право: учебник: в 2 т. / О. Г. Алексеева, Е. Р. Аминов, М. В.Бандо и др.; под ред. Б. М. Гонгало. 3-е изд., перераб. и доп. М.: Статут, 2018. Т. 2.- С. 560;

2. Новак Д. В. Неосновательное обогащение в гражданском праве / Российская школа частного права.- Москва: Статут, 2010.- С. 416;

3. Шраге Э. Несправедливое обогащение / В кн.: Юридическая наука и преподавание права: проблемы и перспективы. Международный сборник научных трудов / Под ред.д.ю.н., проф. В.В.Бойцовой, д.ю.н., проф. Л.В.Бойцовой.- Тверь, 1996.-89-108 с.;

4. Дементьев И. В. Проблемы компетенции налоговых органов в контексте Постановления КС РФ от 24 марта 2017 г. N 9-П // Финансовое право. 2018. N 1 - С. 33-37;

5. Гражданский кодекс Российской Федерации. Постатейный комментарий к главам 1, 2, 3 / Б. М.Гонгало, А. В. Коновалов, П. В. Крашенинников и др.; под ред. П. В. Крашенинникова. М.: Статут, 2013.- С. 336.

6. Карасева (Сенцова) М.В. Гражданско-правовые меры принуждения в налоговой сфере и защита прав налогоплательщиков // Финансовое право. 2017. N 10.- С. 27-31.

\section{Судебная практика}

1. Постановление Конституционного Суда РФ от 24.03.2017 N 9-П «По делу о проверке конституционности отдельных положений Налогового кодекса Российской Федерации и Гражданского кодекса Российской Федерации в связи с жалобами граждан Е.Н.Беспутина, А. В. Кульбацкого и В.А. Чапланова» // «Вестник Конституционного Суда РФ», N 4, 2017; 
2. Постановление Конституционного Суда РФ от 16.07.2004 N 14-П «По делу о проверке конституционности отдельных положений части второй статьи 89 Налогового кодекса Российской Федерации в связи с жалобами граждан А. Д. Егорова и Н. В. Чуева» // «Вестник Конституционного Суда РФ», N 6, 2004;

3. Постановление Пленума Верховного Суда РФ от 24.03.2016 N 7 «О применении судами некоторых положений Гражданского кодекса Российской Федерации об ответственности за нарушение обязательств» // «Российская газета», N 70, 04.04.2016;

4. Постановление Пленума Верховного Суда РФ N 6, Пленума ВАС РФ N 8 от 01.07.1996 «О некоторых вопросах, связанных с применением части первой Гражданского кодекса Российской Федерации»// «Российская газета», N 152, 13.08.1996. 